\title{
Application of System Biology to Explore the Association of Neprilysin, Angiotensin- Converting Enzyme 2 (ACE2), and Carbonic Anhydrase (CA) in Pathogenesis of SARS-CoV-2
}

\author{
Reza Zolfaghari Emameh ${ }^{1 *}$ (D) Reza Falak ${ }^{2}$ and Elham Bahreini ${ }^{3}$
}

\begin{abstract}
Background: Coronavirus disease 2019 (COVID-19) is caused by severe acute respiratory syndrome coronavirus 2 (SARS-CoV-2) appears with common symptoms including fever, dry cough, and fatigue, as well as some less common sysmptoms such as loss of taste and smell, diarrhea, skin rashes and discoloration of fingers. COVID-19 patients may also suffer from serious symptoms including shortness of breathing, chest pressure and pain, as well as loss of daily routine habits, pointing out to a sever reduction in the quality of life. COVID-19 has afftected almost all countries, however, the United States contains the highest number of infection (> 1,595,000 cases) and deaths cases (>95,000 deaths) in the world until May 21, 2020. Finding an influential treatment strategy against COVID-19 can be facilitated through better understanding of the virus pathogenesis and consequently interrupting the biochemical pathways that the virus may play role in human body as the current reservoir of the virus.

Results: In this study, we combined system biology and bioinformatic approaches to define the role of coexpression of angiotensin-converting enzyme 2 (ACE2), neprilysin or membrane metallo-endopeptidase (MME), and carbonic anhydrases (CAs) and their association in the pathogenesis of SARS-CoV-2. The results revealed that ACE2 as the cellular attachment site of SARS-CoV-2, neprilysin, and CAs have a great contribution together in the renin angiotensin system (RAS) and consequently in pathogenesis of SARS-CoV-2 in the vital organs such as respiratory, renal, and blood circulation systems. Any disorder in neprilysin, ACE2, and CAs can lead to increase of $\mathrm{CO}_{2}$ concentration in blood and respiratory acidosis, induction of pulmonary edema and heart and renal failures.

Conclusions: Due to the presence of ACE2-Neprilysin-CA complex in most of vital organs and as a receptor of COVID-19, it is expected that most organs are affected by SARS-CoV-2 such as inflammation and fibrosis of lungs, which may conversely affect their vital functions, temporary or permanently, sometimes leading to death. Therefore, ACE2-Neprilysin-CA complex could be the key factor of pathogenesis of SARS-CoV-2 and may provide us useful information to find better provocative and therapeutic strategies against COVID-19.

(Continued on next page)
\end{abstract}

\footnotetext{
* Correspondence: zolfaghari@nigeb.ac.ir

${ }^{1}$ Department of Energy and Environmental Biotechnology, National Institute of Genetic Engineering and Biotechnology (NIGEB), 14965/161, Tehran, Iran Full list of author information is available at the end of the article
}

C C The Author(s). 2020 Open Access This article is licensed under a Creative Commons Attribution 4.0 International License, which permits use, sharing, adaptation, distribution and reproduction in any medium or format, as long as you give appropriate credit to the original author(s) and the source, provide a link to the Creative Commons licence, and indicate if changes were made. The images or other third party material in this article are included in the article's Creative Commons licence, unless indicated otherwise in a credit line to the material. If material is not included in the article's Creative Commons licence and your intended use is not permitted by statutory regulation or exceeds the permitted use, you will need to obtain permission directly from the copyright holder. To view a copy of this licence, visit http://creativecommons.org/licenses/by/4.0/ The Creative Commons Public Domain Dedication waiver (http://creativecommons.org/publicdomain/zero/1.0/) applies to the data made available in this article, unless otherwise stated in a credit line to the data. 
(Continued from previous page)

Keywords: SARS-CoV-2, COVID-19, Angiotensin-converting enzyme 2 (ACE2), Neprilysin, Carbonic anhydrases (CAs), Renin angiotensin system (RAS), Acute respiratory syndrome, Respiratory acidosis

\section{Background}

Since the emergence of severe acute respiratory syndrome coronavirus 2 (SARS-CoV-2) and the worldwide outbreak of coronavirus disease 2019 (COVID-19), the number of infected and death cases have exceeded 4,300,000 and 290,000, respectively until May 21, 2020. Taken together all the observations, world health organization (WHO) declared COVID-19 as a pandemic viral infection based on the prevalence rate and severity of the disease $[1,2]$ (Table 1$)$.

The COVID-19 patients suffer from several clinical symtoms including fever, dry cough, fatigue, headache, sore throat, loss of taste and smell, aches and pains, diarrhea, skin rashes and/or discoloration of fingers and toes, shortness of breathing, chest pressure and pain, and loss of speech and movement. Since the outbreak of COVID-19 around the world, many academic groups and pharmaceutical companies have focused on developing therapeutic compounds to provide an effective vaccine against COVID-19. The studies revealed that remdesivir [3], combination of lopinavir and ritonavir (weak recommendation) [4], corticosteroids [5], interferon along with combination of lopinavir and ritonavir [4], and immunoglobulin-therapy through transfusion of immune plasma can be the possible thearapetic options for treatment of COVID-19. For COVID-19 prevention, the studies can focus on the results obtained from SARS-CoV vaccine clinical trials such as application of DNA, viral vector, subunit, viral-like particle, inactivated virus, and live-attenuated virus platforms [6].

To achieve an effective treatment, it is necessary to know more about the mechanism of action and pathogenesis of SARS-CoV-2. Four structural proteins including spike (S), membrane $(\mathrm{M})$, nucleocapsid $(\mathrm{N})$, and envelope (E) antigens are the main constituents of SARS-CoV-2 [7]. S protein is a $150 \mathrm{kDa}$ glycoprotein with a $\mathrm{N}$-terminal signal peptide sequence, which is glycosylated at endoplasmic reticulum (ER) [8]. The most abundant structural protein is $M$ protein $(25-30 \mathrm{kDa})$ comprising three transmembrane domains with crucial roles in the virion formation and stabilizing the complexes during the virion assembly through binding of a small glycosylated N-terminal region of $\mathrm{M}$ protein to $\mathrm{N}$ protein [9]. N protein $(50-60 \mathrm{kDa})$ binds to RNA through $\mathrm{N}$-terminal domain (NTD) and C-terminal domain (CTD), which is induced by phosphorylation of $\mathrm{N}$ protein, genomic packaging signal (GPS), replicase-transcriptase complex (RTC), and transcription regulatory signal (TRS)

Table 1 Statistics of worldwide COVID-19 cases until May 21, 2020

\begin{tabular}{|c|c|c|c|c|}
\hline Continent & $\begin{array}{l}\text { Country (top } 3 \text { countries } \\
\text { for confirmed cases) }\end{array}$ & Confirmed cases & Deaths & Recovered cases \\
\hline \multirow[t]{3}{*}{ Asia } & Iran & $>129,000$ & $>7250$ & $>100,560$ \\
\hline & India & $>113,300$ & $>3450$ & $>45,900$ \\
\hline & China & $>82,960$ & $>4600$ & $>78,200$ \\
\hline \multirow[t]{3}{*}{ Europe } & Russia & $>317,500$ & $>3100$ & $>92,600$ \\
\hline & Spain & $>279,500$ & $>27,900$ & $>197,000$ \\
\hline & UK & $>248,300$ & $>35,700$ & N/A \\
\hline \multirow[t]{3}{*}{ North America } & United States & $>1,595,000$ & $>95,000$ & $>371,000$ \\
\hline & Canada & $>80,100$ & $>6000$ & $>40,800$ \\
\hline & Mexico & $>56,600$ & $>6100$ & $>38,900$ \\
\hline \multirow[t]{3}{*}{ South America } & Brazil & $>294,100$ & $>19,000$ & $>117,000$ \\
\hline & Peru & $>104,000$ & $>3000$ & $>42,000$ \\
\hline & Chile & $>53,600$ & $>544$ & $>22,500$ \\
\hline \multirow[t]{3}{*}{ Africa } & South Africa & $>18,000$ & $>340$ & $>9000$ \\
\hline & Egypt & $>14,200$ & $>680$ & $>4000$ \\
\hline & Morocco & $>7200$ & $>200$ & $>4200$ \\
\hline \multirow[t]{3}{*}{ Oceania } & Australia & $>7100$ & $>100$ & $>6500$ \\
\hline & New Zealand & $>1500$ & $>20$ & $>1450$ \\
\hline & French Polynesia & $>60$ & 0 & $>60$ \\
\hline
\end{tabular}


[10]. E protein $(8-12 \mathrm{kDa})$ is a transmembrane protein with ion channel activity and a major role in assembly and release of virions from the infected cells [11]. Although E protein is not required for replication of the virus, it it plays role in pathogenesis of SARS-CoVs.

At the cellular level, the first viral entry step is the binding of the viral trimeric $S$ protein to the human angiotensin converting enzyme 2 (ACE2) receptor [12]. Moreover, CD147 [13], dendritic cell-specific intercellular adhesion molecule-3grabbing non-integrin (DC-SIGN, CD209) [14] and L-SIGN (CD209L) [15] are other entry receptors for SARS-CoV-2. ACE2 is a glycosylated zinc metallopeptidase and a part of the local renin-angiotensin system (RAS). Based on native function of type I membranous endopeptidases in modification of N-terminal region of proteins, ACE2 contains an extracellular N-terminal active site [16]. This enzyme is expressed in most tissues including kidneys, heart, intestine and lungs, and hydrolyse circulating angiotensisn molecules. ACE2 counteracts the effects of ACE by converting angiotensin I into Ang-(1-7) and reducing the amount of angiotensin II and balancing the ratio of circulating Ang II/ Ang-(1-7) levels [17, 18]. Elevated Ang II production in the pulmonary system triggers local vascular permeability which may result in lung edema $[19,20]$. Moreover, Ang II induces pulmonary vasoconstriction in response to hypoxia. Ang-(1-7) has vasodilator, antiproliferative, and anti-angiogenic properties, while Ang II is a vasoconstrictor, a mitogenic, and an angiogenic factor [21].

In acute respiratory distress syndrome (ARDS), if the RAS does not help in oxygenation, the general lung injury will result in pulmonary failure. Most probably, in ARDS models, ACE2 knockout will result in more severe symptoms, while overexpression might protect the lung from further injury [22].

As mentioned, ACE2 is also exploited by SARS-CoV-2 as the entry receptor. Due to the high expression of ACE2 in the lungs, intestines, respiratory tract, and also enteric system, these organs are the main sites of SARS-CoV-2 infections that are manifested by symptoms like fever, cough, pneumonia, shortness or difficulty of breathing, anorexia, sometimes diarrhea, and abdominal pain [23]. Therefore, it is considered that coronavirus infection can be controlled by blocking ACE2 and preventing the virus from binding to the cells [12]. Despite the mentioned assumption, some animal studies have shown that an increase in Ang-(1-7) has a protective effect against virus-induced lung injury via the vasodilatory effects $[22,24]$. It seems that, persistent angiotensin II activity may be partly responsible for organ injury in COVID-19 [19].

Due to insufficient information on the infectious mechanism of the virus, most studies have focused on preventing the first stage of viral infection by reducing ACE2, but ACE2 knock down leads to high activation of local RAS and increased tissue injury, hypertension and renal and cardiovascular complications. Therefore, the evaluation of the efficacy of recently designed vaccines for COVID-19 requires appropriate animal models such as ACE2-transgenic and ACE2-knockout mice [25].

Although, ACE2 is the major producer of Ang-(1-7), there are other enzymes such as neprilysin, prolyl-endopeptidase (PEP) and prolyl-carboxy-peptidase (PCP) that can produce Ang-(1-7) from Ang I [26, 27]. Among the aforementioned enzymes, high expression levels of neprilysin have been detected in the lung, especially in pulmonary epithelial cells [21]. This zinc-dependent MME is expressed in a wide variety of tissues and in addition to hydrolyzing the Ang I to Ang-(1-7), it is involved in converting several endogenous propeptides into their functional form. According to evidence, neprilysin regulates lung tissue responses to broncho-constriction inducing peptides [21, 28]. Thus, upregulation of neprilysin can be considered as a compensatory mechanism to control the concentration of Ang-(1-7) levels during COVID-19 treatment.

Airway management and hyperbaric oxygen therapy (HBOT) is the main supportive treatments for patients with severe COVID-19 as well as severe pneumonia [29]. Previous studies have revealed that the levels of both angiotensinogen and Ang II receptors increases in hypoxic conditions [30,31]. Consequently, hypoxic conditions in COVID-19 will increase Ang II concentration through downregulation of ACE2 [32, 33]. Lungs and alveoli as the main parts of lower respiratory system have the main role in the oxygen $\left(\mathrm{O}_{2}\right)$ exchange with carbon dioxide $\left(\mathrm{CO}_{2}\right)$ at the molecular level; CA plays a crucial function in this respiratory exchange $[34,35]$. CA as another Zn-metalloenzyme catalyzes the hydration of $\mathrm{CO}_{2}$ into carbonic acid and vice versa [36-38]. One of the adaptive responses to hypoxia includes the increased expression and functional activation of CA IX [39]. In this study, we applied a system biology approach to explore the association of ACE2, neprilysin, and $\mathrm{CA}$, which may ameliorate COVID-19 symptoms in the lungs alveoli.

\section{Methods}

Identification of Coexpression of ACE2, Neprilysin, and CA To identify role of coexpression of ACE2, neprilysin, and CA in COVID-19 pathogenesis, we used COXPRESdb v7 (https://coxpresdb.jp/) [40]. In this database, we applied the CoexViwer algorithm to identify and draw the coexpression of genes, which are linked to activation of neprilysin. This database facilitates the visualization of the multiple gene coexpression information derived from defined animals which were examined with a variety of transcriptomics technologies.

\section{Identification of the Association of Neprilysin and ACE2}

To identify the association of neprilysin and ACE2, we employed KEGG (Kyoto Encyclopedia of Genes and 
Genomes) PATHWAY database [41]. This database represents the information on the reactions, relation networks, and molecular interactions of the molecules.

\section{Identification of Organ Localization of ACE2, Neprilysin, and $C A$}

To identify the organ localization of ACE2, neprilysin, and CA, we used THE HUMAN PROTEIN ATLAS online program (https://www.proteinatlas.org/) [42]. This program shows the map of the localization of human proteins in cells, organs, and tissues through application of various system biology, proteomics, and transcriptomics technologies.

\section{Results}

Identification of Coexpression of ACE2, Neprilysin, and CA The coexpression study revealed that ACE2, neprilysin, and CA are codominantly expressed in the local RAS.
The analysis showed that at least 22 genes were coexpressed in the local RAS, which can be linked to COVID-19. This association can be a direct or an indirect coexpression effect; so lack of function of a protein as the consequence of COVID-19 infection may induce the expression or activity of another protein in a different pathway (Fig. 1) (Table 2).

\section{Identification of Association of Neprilysin and ACE2}

The KEGG PATHWAY defined that neprilysin and ACE2 have association in the RAS. In this system, via two individual biochemical procedures, neprilysin converts Ang I and Ang-(1-9) to Ang-(1-7). In addition, in the RAS, ACE2 facilitates three individual biochemical procedures including conversion of Ang 1 to Ang-(1-9) as the substrate of neprilysin, Ang II to Ang-(1-7), and Ang A to alamandine which binds to Mas-related G

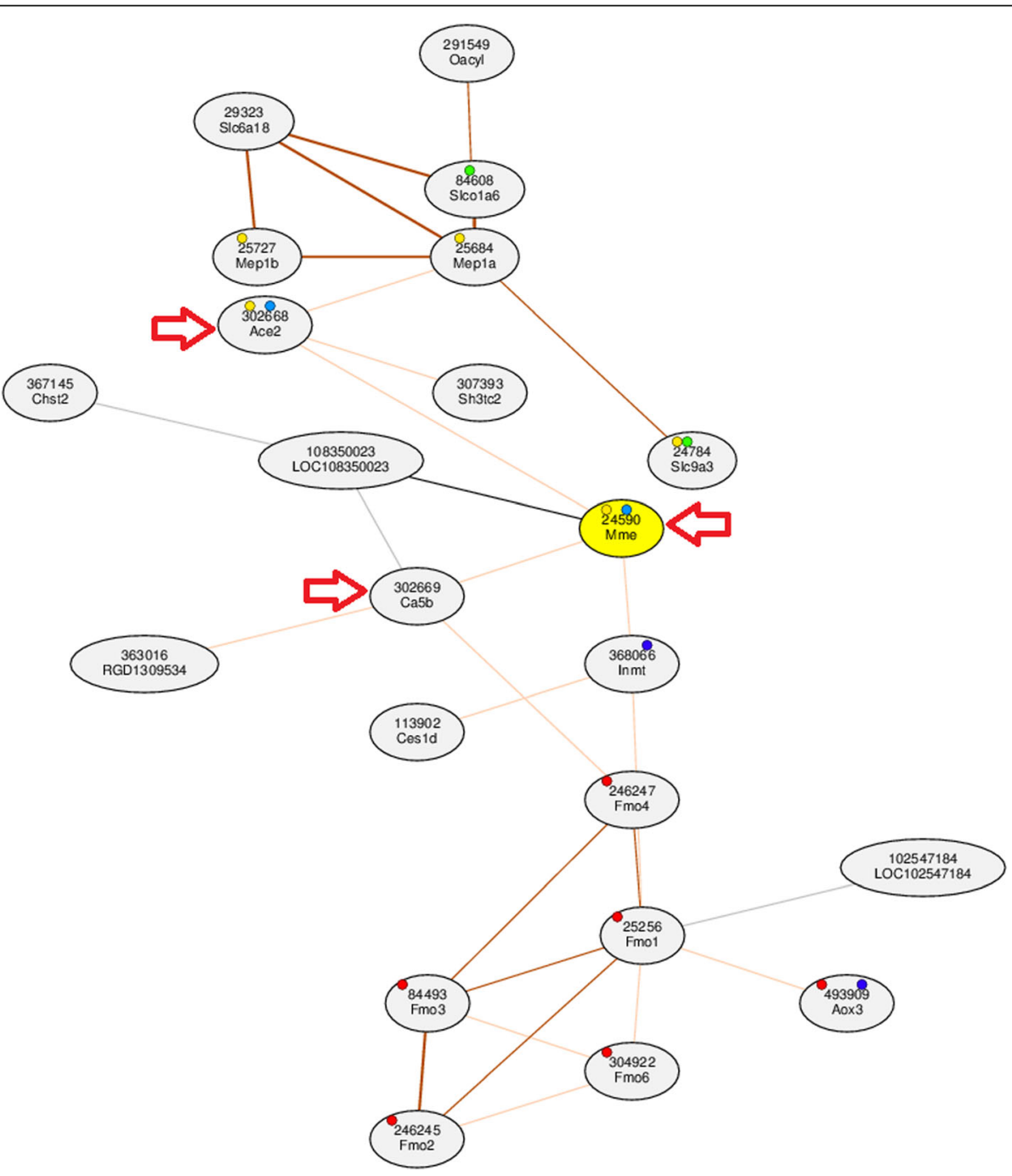

Fig. 1 Coexpression of ACE2, neprilysin or MME, and CA in RAS. Red arrows are showing ACE2-Neprilysin-CA association network. The network consist of 22 proteins that two out of them are still not characterized 
Table 2 Genes directly connected with neprilysin on the coexpression network

\begin{tabular}{lll}
\hline Locus & Function & Entrez Gene ID \\
\hline CA VB & carbonic anhydrase 5B & 302,669 \\
ACE2 & angiotensin-converting enzyme 2 & 302,668 \\
\hline
\end{tabular}

protein-coupled receptor (MrgprD) to perform the vasodilatory action (Fig. 2).

\section{Identification of Organ Localization of ACE2, Neprilysin, and CA}

Our analysis based on the data obtained from THE HUMAN PROTEIN ATLAS revealed that neprilysin and
ACE2 are highly expressed in the digestive, renal, respiratory, and reproductive systems. The expression pattern of CA in the atlas has shown that this protein is expressed in all human organs. These overlaps in the organ localization of ACE2, neprilysin, and CA demonstrate the possible association of these proteins as a complex in COVID-19 infections through overexpression or down regulation of coding genes expression (Fig. 3).

\section{Discussion}

The successful computational methodologies were employed previously to design viral vaccines against influenza A, hepatitis A, HIV-1, dengue, and West Nile viruses so a new era was considered in the vaccine

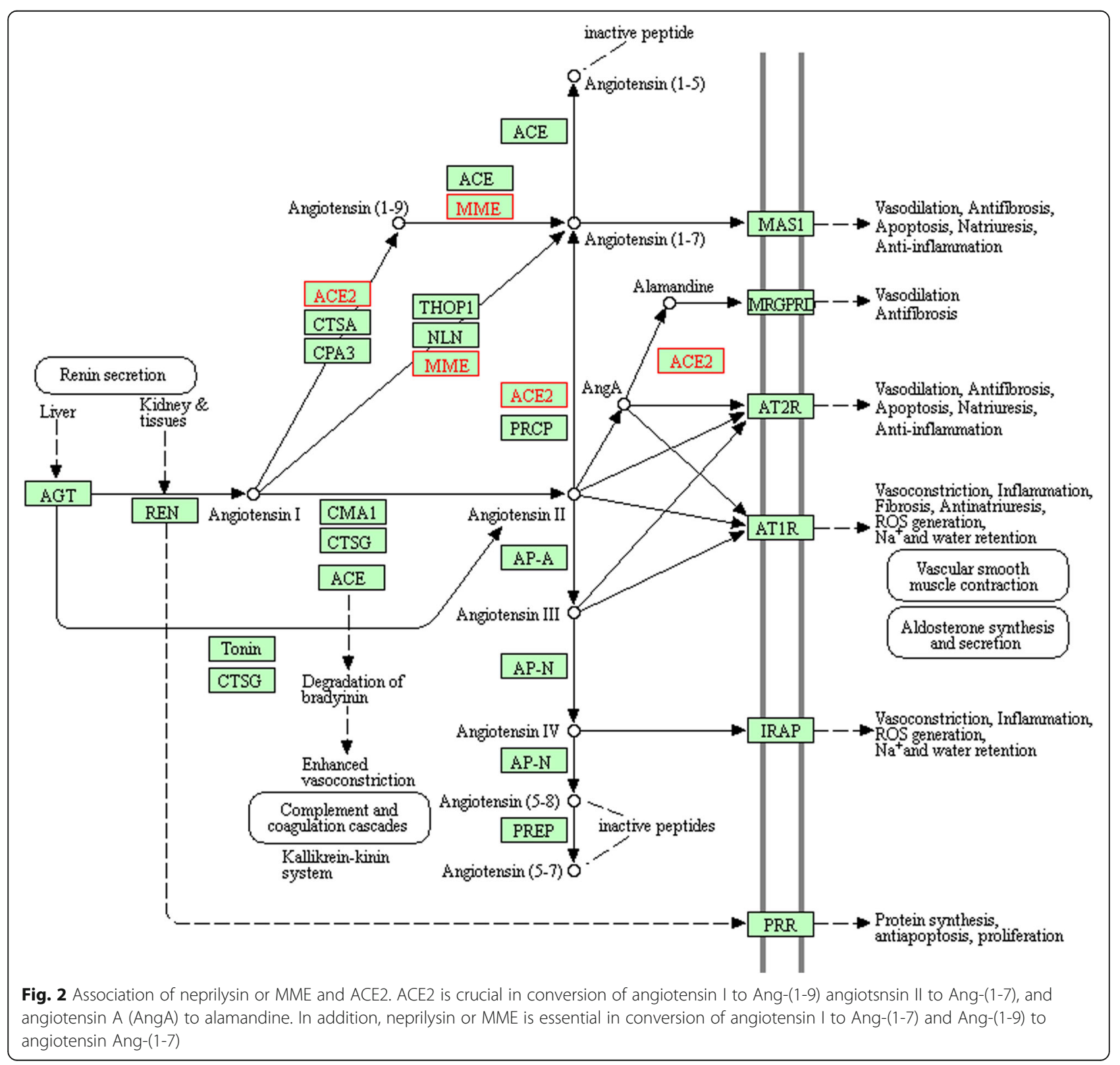




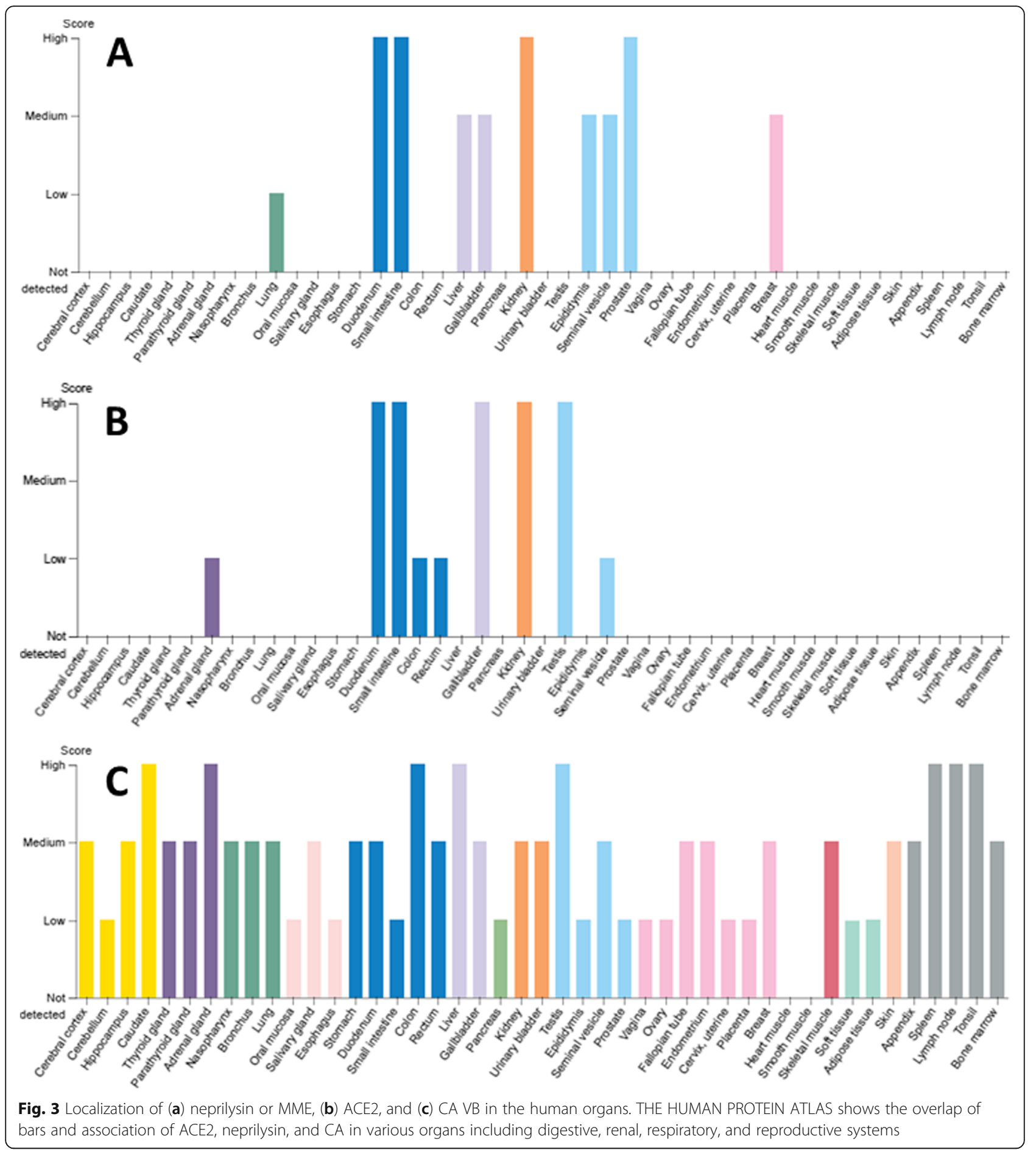

design studies, which was named reverse vaccinology 2.0 [43-45]. This approach was designed and implemented to demonstrate the importance of combination of human immunology, clinical biochemistry, microbial genomics, and system biology to establish novel multidisciplinary approaches in the pathogenesis studies of pathogens and vaccinology researches $[45,46]$.
The bioinformatics analysis reveals the moderate coexpression of ACE2, neprilysin, and CA genes in the human body. As soon as SARS-CoV-2 is entered into the human oral cavity via direct contact or sneezing and cough droplets of a COVID-19 patient, the virus S protein can be attached to the ACE2, the main host cell receptor of SARS-CoV-2 expressed by epithelial cells of 
different sites of the oral cavity [47, 48]. Single-cell transcriptome study revealed that the expression rate of ACE2 in the tongue tissue is higher than buccal and gingival tissues [49]. Therefore, primarily SARS-CoV-2 multiplicities in the human mucosa of the oral cavity and consequently a high number of viruses are transmitted to the secondary organ targets expressing ACE2. For this reason, some have claimed drinking water could be a safe way against SARS-CoV-2 which wash the virus into the stomach where acid will inactivate it.

Single-cell sequencing (scRNA-Seq) has shown a high expression rate for ACE2 in type II alveolar (AT2) cells of lung [50], oral cavity epithelial cells [51], upper esophagus [14] and cholangiocytes [52]. A reduction in ACE2 levels due to internalizing by attached SARS$\mathrm{CoV}-2$ leads to increase in Ang II and consequently vasoconstriction in the lung [53]. Such condition causes respiratory disorders and insufficient air conditioning in alveoli which stimulates lung to upregulate ACE2 expression [54]. According to bioinformatics predictionof the coexpression of ACE2, neprilysin, and CA; an increase in neprilysin and upregulation of CA may attenuate the severity of disease and compensate the alveolar ventilation [55-59]. The elevated Ang II in lung tissue following a decrease in ACE2 by COVID-19 binding may increase the comorbidities, most likely due to inducing local and systemic inflammation. The proinflammatory effects of Ang II are mediated by increased oxidative stress. Elevated serum concentrations of C-reactive protein (CRP) is an indicator of systemic inflammation in such conditions [60].

ACE2 also is expressed in other tissues including proximal tubular cells of kidney [61], colon and ileum of the digestive system [62], urothelial cells of the gallbladder [49], and liver, pancreas and heart myocytes [63], which can justify COVID-19 infection side effects. ACE2 is also expressed in lymphocytes and following infection with the virus, their population decreases and the immune system weakens [13].

Also, different isoenzymes of CA have a high rate of expression in various tissues with critical biochemical functions in the $\mathrm{pH}$ homeostasis and alveolar $\mathrm{O}_{2}-\mathrm{CO}_{2}$ exchange [64]. After the inhalation, the oxygen is entered to alveoli of lungs with higher pressure than blood capillaries and delivered to hemoglobin in red blood cells (RBCs) [65]. Then, $\mathrm{H}_{2} \mathrm{CO}_{3}$ is catalyzed to $\mathrm{CO}_{2}$ and water molecule by CA 11 of RBCs. In the acute COVID-19, following the destructive effects of virus on the pulmonary cells, the $\mathrm{O}_{2}-\mathrm{CO}_{2}$ exchange rate is impaired, leading to respiratory acidosis and shifting the $\mathrm{pH}$ of blood to acidic state and also increasing the concentration of blood $\mathrm{CO}_{2}$ [66]. Subsequently, the kidney proximal tubular cells increase reabsorption of $\mathrm{HCO}_{3}{ }^{-}$leading to acid and ammonium excretion [67]. Then, $\mathrm{H}^{+}$of the tubular fluid is combined with $\mathrm{HCO}_{3}{ }^{-}$producing $\mathrm{H}_{2} \mathrm{CO}_{3}$, which is catalyzed to $\mathrm{H}_{2} \mathrm{O}$ and $\mathrm{CO}_{2}$ by CAs localized in kidney tissue [68]. Hence, as the consequence of infection of various cells including pulmonary cells of lungs, myocytes of heart, proximal tubular cells of kidney, and other ACE2expressing cells (which mainly express CAs) with SARS$\mathrm{CoV}-2$ and reducing the ability of $\mathrm{CO}_{2}$ exhalation, the concentration of blood $\mathrm{CO}_{2}$ is elevated so even the lungs alveoli became unable in $\mathrm{O}_{2}-\mathrm{CO}_{2}$ exchange with pulmonary artery and vein through the $\mathrm{CA}$ enzymatic reaction [69]. The respiratory acidosis is associated with weakness of the respiratory muscles, arrhythmias, hypotension, myocardial depression, and decreasing in renal blood flow [66]. As the immunological aspect, the respiratory acidosis induces apoptosis and release of proinflammatory cytokines following RAS activation and raising the expression level of angiotensinogen by leukocytes [70]. Finally, the respiratory acidosis can lead to pulmonary edema, severe hypoxia as well as heart and renal failures [66]. Regarding to coexpression analyses results and referring to lack of sufficient information related to human $C A V B$, we couldn't find the reason of the coexpression prediction of neprilysin and ACE2 with CA VB, which needs further experiments in future.

\section{Conclusions}

Overally, due to high expression rate of ACE2 in the human organs and presence of a potential association with neprilysin in RAS and CAs, SARS-CoV-2 could be considered as an aggressive pathogen to all human organs which express ACE2. Therefore, this pathologic association (ACE2-Neprilysin-CA) complex can present valuable physiologic information to clinicians to innovate more influential treatment protocols against COVID-19.

\section{Abbreviations}

ACE2: Angiotensin-converting enzyme 2; ARDS: Acute respiratory distress syndrome; $\mathrm{HCO}_{3}^{-}$: Bicarbonate; $\mathrm{H}_{2} \mathrm{CO}_{3}$ : Carbonic acid; $\mathrm{CA}$ : Carbonic

anhydrase; COVID-19: Coronavirus disease 2019; $\mathrm{CO}_{2}$ : Carbon dioxide; CRP: Creactive protein; DC-SIGN: Dendritic cell-specific intercellular adhesion

molecule-3-grabbing non-integrin; E: Envelope; HBOT: Hyperbaric oxygen therapy; HIV: Human immunodeficiency virus; KEGG: Kyoto Encyclopedia of Genes and Genomes; M: Membrane; MME: Membrane metalloendopeptidase; MrgprD: Mas-related G protein-coupled receptor;

$\mathrm{N}$ : Nucleocapsid; $\mathrm{O}_{2}$ : Oxygen; RAS: Renin angiotensin system; RBC: Red blood cell; S: Spike; SARS-CoV-2: Severe acute respiratory syndrome coronavirus 2

\section{Acknowledgements}

We thank the Deputy of Research and COVID-19 National Committee at the National Institute of Genetic Engineering and Biotechnology (NIGEB) of the Islamic Republic of Iran for preparing the condition to perform this study. No funding organizations had any role in the design of the study; in the collection, analyses, or interpretation of data; in the writing of the manuscript; nor in the decision to publish the results.

\section{Authors' Contributions}

All authors participated in the design of the study. RZE designed and carried out the search and data mining related to the coexpression of ACE2-

Neprilysin-CA complex as well as databases for this study. RZE performed the system biology and bioinformatic studies. RF participated in the

immunological and EB participated in the biochemical studies and further 
revision of the manuscript. All authors participated in writing further versions and read and approved the final manuscript.

\section{Funding}

To perform this study, RZE received a research grant support from the National Institute of Genetic Engineering and Biotechnology (NIGEB) of the Islamic Republic of Iran.

\section{Availability of Data and Materials}

All data analyzed in this study were prepared from online databases, which were included in this article.

\section{Ethics Approval and Consent to Participate}

Not applicable.

\section{Consent for Publication}

All authors have read and approved the final version of the manuscript.

\section{Competing Interests}

The authors declare that they have no conflict of interests.

\section{Author details}

'Department of Energy and Environmental Biotechnology, National Institute of Genetic Engineering and Biotechnology (NIGEB), 14965/161, Tehran, Iran. ${ }^{2}$ Immunology Research Center, Iran University of Medical Sciences, Tehran, Iran. ${ }^{3}$ Department of Biochemistry, Faculty of Medicine, Iran University of Medical Sciences, Tehran, Iran.

\section{Received: 20 April 2020 Accepted: 1 June 2020}

Published online: 19 June 2020

\section{References}

1. Mahase E. Covid-19: WHO declares pandemic because of "alarming levels" of spread, severity, and inaction. BMJ. 2020;368:m1036.

2. Zolfaghari Emameh $\mathrm{R}$, Nosrati $\mathrm{H}$, Taheri RA. Combination of biodata mining and computational modelling in identification and characterization of ORF1ab polyprotein of SARS-CoV-2 isolated from Oronasopharynx of an Iranian patient. Biol Proced Online. 2020;22:8.

3. Grein J, Ohmagari N, Shin D, Diaz G, Asperges E, Castagna A, et al. Compassionate use of Remdesivir for patients with severe Covid-19. N Engl J Med. 2020;NEJMoa2007016.

4. Jin $\mathrm{YH}$, Cai L, Cheng ZS, Cheng H, Deng T, Fan YP, et al. A rapid advice guideline for the diagnosis and treatment of 2019 novel coronavirus (2019nCoV) infected pneumonia (standard version). Mil Med Res. 2020;7(1):4.

5. Russell CD, Millar JE, Baillie JK. Clinical evidence does not support corticosteroid treatment for 2019-nCoV lung injury. Lancet. 2020; 395(10223):473-5

6. Prompetchara E, Ketloy C, Palaga T. Immune responses in COVID-19 and potential vaccines: lessons learned from SARS and MERS epidemic. Asian Pac J Allergy Immunol. 2020;38(1):1-9.

7. McBride R, van Zyl M, Fielding BC. The coronavirus nucleocapsid is a multifunctional protein. Viruses. 2014;6(8):2991-3018.

8. Belouzard S, Millet JK, Licitra BN, Whittaker GR. Mechanisms of coronavirus cell entry mediated by the viral spike protein. Viruses. 2012;4(6):1011-33.

9. Arndt AL, Larson BJ, Hogue BG. A conserved domain in the coronavirus membrane protein tail is important for virus assembly. J Virol. 2010;84(21): $11418-28$.

10. Zuniga S, Cruz JL, Sola I, Mateos-Gomez PA, Palacio L, Enjuanes L. Coronavirus nucleocapsid protein facilitates template switching and is required for efficient transcription. J Virol. 2010;84(4):2169-75.

11. Verdia-Baguena C, Nieto-Torres JL, Alcaraz A, DeDiego ML, Torres J, Aguilella VM, et al. Coronavirus E protein forms ion channels with functionally and structurally-involved membrane lipids. Virology. 2012;432(2):485-94.

12. Yan R, Zhang Y, Li Y, Xia L, Guo Y, Zhou Q. Structural basis for the recognition of SARS-CoV-2 by full-length human ACE2. Science. 2020; 367(6485):1444-8.

13. Wang X, Xu W, Hu G, Xia S, Sun Z, Liu Z, et al. SARS-CoV-2 infects T lymphocytes through its spike protein-mediated membrane fusion. Cell Mol Immunol. 2020:1-3.
14. Qi F, Qian S, Zhang S, Zhang Z. Single cell RNA sequencing of 13 human tissues identify cell types and receptors of human coronaviruses. Biochem Biophys Res Commun. 2020;526(1):135-40.

15. Jeffers SA, Tusell SM, Gillim-Ross L, Hemmila EM, Achenbach JE, Babcock GJ, et al. CD209L (L-SIGN) is a receptor for severe acute respiratory syndrome coronavirus. Proc Natl Acad Sci U S A. 2004;101(44):15748-53.

16. Varland S, Osberg C, Arnesen T. N-terminal modifications of cellular proteins: the enzymes involved, their substrate specificities and biological effects. Proteomics. 2015;15(14):2385-401.

17. Paul M, Poyan Mehr A, Kreutz R. Physiology of local renin-angiotensin systems. Physiol Rev. 2006;86(3):747-803.

18. Gandhi C, Uhal BD. Roles of the angiotensin system in neonatal lung injury and disease. JSM Atheroscler. 2016;1(3):1014

19. Deng J, Wang DX, Deng W, Li CY, Tong J. The effect of endogenous angiotensin II on alveolar fluid clearance in rats with acute lung injury. Can Respir J. 2012;19(5):311-8.

20. Imai $Y$, Kuba K, Penninger JM. The renin-angiotensin system in acute respiratory distress syndrome. Drug Discov Today Dis Mech. 2006;3(2):225-9.

21. Gallagher PE, Cook K, Soto-Pantoja D, Menon J, Tallant EA. Angiotensin peptides and lung cancer. Curr Cancer Drug Targets. 2011;11(4):394-404.

22. Imai $Y$, Kuba K, Penninger JM. The discovery of angiotensin-converting enzyme 2 and its role in acute lung injury in mice. Exp Physiol. 2008; 93(5):543-8.

23. Adhikari SP, Meng S, Wu YJ, Mao YP, Ye RX, Wang QZ, et al. Epidemiology, causes, clinical manifestation and diagnosis, prevention and control of coronavirus disease (COVID-19) during the early outbreak period: a scoping review. Infect Dis Poverty. 2020;9(1):29.

24. Jia H. Pulmonary angiotensin-converting enzyme 2 (ACE2) and inflammatory lung disease. Shock (Augusta, Ga). 2016;46(3):239-48.

25. Imai Y, Kuba K, Rao S, Huan Y, Guo F, Guan B, et al. Angiotensinconverting enzyme 2 protects from severe acute lung failure. Nature. 2005:436(7047):112-6.

26. Grobe N, Weir NM, Leiva O, Ong FS, Bernstein KE, Schmaier AH, et al. Identification of prolyl carboxypeptidase as an alternative enzyme for processing of renal angiotensin II using mass spectrometry. Am J Phys Cell Phys. 2013;304(10):C945-53.

27. Domenig O, Manzel A, Grobe N, Konigshausen E, Kaltenecker CC, Kovarik JJ, et al. Neprilysin is a mediator of alternative renin-angiotensin-system activation in the murine and human kidney. Sci Rep. 2016;6:33678.

28. Wick MJ, Buesing EJ, Wehling CA, Loomis ZL, Cool CD, Zamora MR, et al. Decreased neprilysin and pulmonary vascular remodeling in chronic obstructive pulmonary disease. Am J Respir Crit Care Med. 2011;183(3):330-40

29. Geier MR, Geier DA. Respiratory conditions in coronavirus disease 2019 (COVID-19): important considerations regarding novel treatment strategies to reduce mortality. Med Hypotheses. 2020;140:109760.

30. Hubloue I, Rondelet B, Kerbaul F, Biarent D, Milani GM, Staroukine M, et al. Endogenous angiotensin $I$ in the regulation of hypoxic pulmonary vasoconstriction in anaesthetized dogs. Crit Care. 2004;8(4):R163-71.

31. Zhao L. al-Tubuly R, Sebkhi a, Owji AA, Nunez DJ, Wilkins MR. angiotensin II receptor expression and inhibition in the chronically hypoxic rat lung. $\mathrm{Br} J$ Pharmacol. 1996;119(6):1217-22.

32. Mohamed TL, Nguyen HT, Abdul-Hafez A, Dang VX, Dang MT, Gewolb IH, et al. Prior hypoxia prevents downregulation of ACE-2 by hyperoxia in fetal human lung fibroblasts. Exp Lung Res. 2016;42(3):121-30.

33. Varagic J, Ahmad S, Nagata S, Ferrario CM. ACE2: angiotensin II/angiotensin(1-7) balance in cardiac and renal injury. Curr Hypertens Rep. 2014;16(3):420.

34. Farhi LE, Plewes $J$, Olszowka AJ. Lung carbonate dehydratase (carbonic anhydrase), CO2 stores and CO2 transport. CIBA Found Symp. 1976;38:235-49.

35. Klocke RA. Catalysis of CO2 reactions by lung carbonic anhydrase. J Appl Physiol Respir Environ Exerc Physiol. 1978;44(6):882-8.

36. Zolfaghari Emameh R, Barker HR, Syrjanen L, Urbanski L, Supuran CT, Parkkila S. Identification and inhibition of carbonic anhydrases from nematodes. J Enzyme Inhib Med Chem. 2016;31(sup4):176-84

37. Zolfaghari Emameh R, Kuuslahti M, Vullo D, Barker HR, Supuran CT, Parkkila S. Ascaris lumbricoides beta carbonic anhydrase: a potential target enzyme for treatment of ascariasis. Parasit Vectors. 2015;8:479.

38. Zolfaghari Emameh R, Kuuslahti M, Nosrati H, Lohi H, Parkkila S. Assessment of databases to determine the validity of beta- and gamma-carbonic anhydrase sequences from vertebrates. BMC Genomics. 2020;21(1):352. 
39. Pastorekova S, Gillies RJ. The role of carbonic anhydrase IX in cancer development: links to hypoxia, acidosis, and beyond. Cancer Metastasis Rev. 2019; 38(1-2):65-77.

40. Obayashi T, Kagaya Y, Aoki Y, Tadaka S, Kinoshita K. COXPRESdb v7: a gene coexpression database for 11 animal species supported by 23 coexpression platforms for technical evaluation and evolutionary inference. Nucleic Acids Res. 2019;47(D1):D55-62.

41. Du J, Yuan Z, Ma Z, Song J, Xie X, Chen Y. KEGG-PATH: Kyoto encyclopedia of genes and genomes-based pathway analysis using a PATH analysis model. Mol BioSyst. 2014;10(9):2441-7.

42. Thul PJ, Lindskog C. The human protein atlas: a spatial map of the human proteome. Protein Sci. 2018;27(1):233-44.

43. Khan AM, Hu Y, Miotto O, Thevasagayam NM, Sukumaran R, Abd Raman HS, et al. Analysis of viral diversity for vaccine target discovery. BMC Med Genet. 2017;10(Suppl 4):78.

44. Hasan M, Ghosh PP, Azim KF, Mukta S, Abir RA, Nahar J, et al. Reverse vaccinology approach to design a novel multi-epitope subunit vaccine against avian influenza a (H7N9) virus. Microb Pathog. 2019;130:19-37.

45. Rappuoli R, Bottomley MJ, D'Oro U, Finco O, De Gregorio E. Reverse vaccinology 2.0: human immunology instructs vaccine antigen design. J Exp Med. 2016;213(4):469-81.

46. Zolfaghari Emameh R, Kuuslahti M, Nareaho A, Sukura A, Parkkila S. Innovative molecular diagnosis of Trichinella species based on betacarbonic anhydrase genomic sequence. Microb Biotechnol. 2016;9(2):172-9.

47. Hoffmann M, Kleine-Weber H, Schroeder S, Kruger N, Herrler T, Erichsen S, et al. SARS-CoV-2 cell entry depends on ACE2 and TMPRSS2 and is blocked by a clinically proven protease inhibitor. Cell. 2020;181(2):271.

48. Lan J, Ge J, Yu J, Shan S, Zhou H, Fan S, et al. Structure of the SARS-CoV-2 spike receptor-binding domain bound to the ACE2 receptor. Nature. 2020; 581(7807):215

49. Xu H, Zhong L, Deng J, Peng J, Dan H, Zeng $X$, et al. High expression of ACE2 receptor of 2019-nCoV on the epithelial cells of oral mucosa. Int J Oral Sci. 2020;12(1):8.

50. Uhal BD, Dang M, Dang V, Llatos R, Cano E, Abdul-Hafez A, et al. Cell cycle dependence of ACE-2 explains downregulation in idiopathic pulmonary fibrosis. Eur Respir J. 2013;42(1):198-210.

51. de Carvalho Fraga CA, Farias LC, Jones KM. Batista de Paula AM, Guimaraes ALS. Angiotensin-converting enzymes (ACE and ACE2) as potential targets for malignant epithelial neoplasia: review and bioinformatics analyses focused in Oral squamous cell carcinoma. Protein Pept Lett. 2017;24(9):784-92.

52. Zhang C, Shi L, Wang FS. Liver injury in COVID-19: management and challenges. Lancet Gastroenterol Hepatol. 2020;5(5):428.

53. South AM, Tomlinson L, Edmonston D, Hiremath S, Sparks MA. Controversies of renin-angiotensin system inhibition during the COVID-19 pandemic. Nat Rev Nephrol. 2020;16(6):305.

54. Li G, He X, Zhang L, Ran Q, Wang J, Xiong A, et al. Assessing ACE2 expression patterns in lung tissues in the pathogenesis of COVID-19. J Autoimmun. 2020;1:102463.

55. Sparks MA, Crowley SD, Gurley SB, Mirotsou M, Coffman TM. Classical reninangiotensin system in kidney physiology. Compr Physiol. 2014;4(3):1201-28.

56. Ahmad S, Varagic J, Groban L, Dell'Italia LJ, Nagata S, Kon ND, et al. Angiotensin-(1-12): a chymase-mediated cellular angiotensin II substrate. Curr Hypertens Rep. 2014;16(5):429.

57. Park S. Ideal target blood pressure in hypertension. Korean Circ J. 2019; 49(11):1002-9.

58. Simoni J, Simoni G, Moeller JF, Tsikouris JP, Wesson DE. Evaluation of angiotensin converting enzyme (ACE)-like activity of acellular hemoglobin Artif Cells Blood Substit Immobil Biotechnol. 2007;35(2):191-210.

59. Patel VB, Zhong JC, Grant MB, Oudit GY. Role of the ACE2/angiotensin 1-7 Axis of the renin-angiotensin system in heart failure. Circ Res. 2016;118(8): 1313-26.

60. Bansal T, Pandey A. D D, Asthana AK. C-reactive protein (CRP) and its association with periodontal disease: a brief review. J Clin Diagn Res. 2014; 8(7):ZE21-4.

61. Soler MJ, Wysocki J, Batlle D. ACE2 alterations in kidney disease. Nephrol Dial Transplant. 2013;28(11):2687-97.

62. Vuille-dit-Bille RN, Camargo SM, Emmenegger L, Sasse T, Kummer E, Jando J, et al. Human intestine luminal ACE2 and amino acid transporter expression increased by ACE-inhibitors. Amino Acids. 2015;47(4):693-705.
63. Gallagher PE, Ferrario CM, Tallant EA. Regulation of ACE2 in cardiac myocytes and fibroblasts. Am J Physiol Heart Circ Physiol. 2008;295(6): H2373-9.

64. Everaert $N$, Willemsen $H$, Hulikova A, Brown $H$, Decuypere $E$, Swietach $P$, et al. The importance of carbonic anhydrase $\|$ in red blood cells during exposure of chicken embryos to CO2. Respir Physiol Neurobiol. 2010;172(3):154-61.

65. Carlson BE, Anderson JC, Raymond GM, Dash RK, Bassingthwaighte JB. Modeling oxygen and carbon dioxide transport and exchange using a closed loop circulatory system. Adv Exp Med Biol. 2008;614:353-60.

66. Bruno CM, Valenti M. Acid-base disorders in patients with chronic obstructive pulmonary disease: a pathophysiological review. J Biomed Biotechnol. 2012;2012:915150.

67. DuBose TD Jr. Carbonic anhydrase-dependent bicarbonate transport in the kidney. Ann N Y Acad Sci. 1984;429:528-37.

68. Frommer JP, Wesson DE, Laski ME, Kurtzman NA. Generation of reabsorptive bicarbonate concentration gradients between vasa recta and papillary tubular fluid after inhibition of carbonic anhydrase in the rat kidney. Ann N Y Acad Sci. 1984;429:541-3.

69. $X u X W, W u X X$, Jiang $X G, X u K J$, Ying $L J, M a C L$, et al. Clinical findings in a group of patients infected with the 2019 novel coronavirus (SARS-Cov-2) outside of Wuhan, China: retrospective case series. BMJ. 2020;368:m606.

70. Liao Z, Chakrabarty A, Mu Y, Bhattacherjee A, Goestch M, Leclair CM, et al. A local inflammatory renin-angiotensin system drives sensory axon sprouting in provoked Vestibulodynia. J Pain. 2017;18(5):511-25.

\section{Publisher's Note}

Springer Nature remains neutral with regard to jurisdictional claims in published maps and institutional affiliations.

\section{Ready to submit your research? Choose BMC and benefit from:}

- fast, convenient online submission

- thorough peer review by experienced researchers in your field

- rapid publication on acceptance

- support for research data, including large and complex data types

- gold Open Access which fosters wider collaboration and increased citations

- maximum visibility for your research: over $100 \mathrm{M}$ website views per year

At BMC, research is always in progress.

Learn more biomedcentral.com/submissions 